\title{
Rare Black Rabbit Taken
}

\author{
W. C. RICHARDSON, Brandon, Manitoba
}

Fifteen year old Clare Hillis hunting near his home 15 miles Northwest of Brandon, Manitoba bagged a pure black Snowshoe or bush rabbit. The rabbit was identified by Dr. R. D. Bird, Dominion Entomologist, as a very rare melanistic form, the direct opposite to an albino For reasons not understood, at rare intervals nature produces a specimen of animal, insect, or bird, where an excess of pigment in the skin results in real or comparative blackness. The rabbit was sent to the Manitoba Provincial Museum where the find was confirmed. The specimen will be retained there. The Museum's records reported a possible "sight" of such a rabbit near The Pas, Manitoba, last June. Stuart Criddle, of Treesbank, who has been keeping records of mammals for many years, recalls only one other melanistic rabbit and that reported around the year 1880 .

Those disapointed elk hunters may be interested to know that in company of Charles D. Bird and Dr.

\section{A Melanistic Gopher}

J. S. Rowe, Winnipeg, Man.

Reading Mr. Yanchinski's article "The Gopher" in the last issue of the Blue Jay reminded me of an observation that may be of interest to Saskatchewan naturalists. Driving south from Big River near Bodmin in early August of 1952 we were suddenly surprised to see two black gophers in typical "picket pin" posture in a grassy roadside clearing. Having seen albinos but never before melanistic forms we stopped with some excitment to get a closer look. With a string snare and a little patience one of the pair was finally caught and dropped in a pail where we could examine him. It was indeed a coal black Citellus richardsonii, resembling exactly, except in coloration, the common yellow-brown flickertail. When we retailed the news in Big River it was found that the local inhabitants have known the black gophers for some time, one man said they have been around for "about forty years."
R. D. Bird, I spent most of Boxing Day roaming the woods south of the Riding Mountain Park. The day was fine and mild and the snow six inches deep with a fresh fall during the night to wipe out old tracks. There were very few elk tracks to be seen although in the afternoon we did find where half a dozen had visited a hay stack bottom not long before we arrived. It looks as if the Department was right in refusing an elk season this year. Tracks of several large Timber Wolves were observed, some measuring almost four inches across. Besides four or five raven, we observed two Goshawks. The bush rabbits in the district were unusually scarce. Possibly they were feeling the hunting pressure of the hawks. Stuart Criddle tells me that the Goshawks are particularly hard on Sharptail and Ruffed Grouse. He thinks thit it is not impossible that the increase and decline in the supply of grouse is tied in with the increase and decline of Goshawks. Ed. Finch of Brandon reports that Patmore's Nursery plot South of Brandon, frequented by grouse and Hungarian Partridge, is also frequented by Goshawks. The hawks were after food, other than the berries which attract the grouse. By the way, a Goshawk can often be brought within gun range by tossing a cap or some other object into the air. The hawks spot such things nearly half a mile away and come to investigate.

\section{A Novel Feed Shelter}

Bill Moncur, Boissevain, Man.

Here is a tip for anyone wishing to put up a feed shelter for our winter birds including upland game. Take a number of ten or twelve-foot poles and put them up in teepee style. Bind securely and tie sheaves of millet and wheat near the top. A shelter of this type should be put on the sunny side of a sheltered spot, such as poplar bluffs or clumps of willows. One will find that in a very short time these feeding spots become very popular. 